\title{
Monitoring of Nuclear Abnormality Frequencies as Indicators of Environmental Pollution in Peripheral Erythrocytes of Labeo rohita Reared in Lakes of Bangalore
}

\author{
Nazima Noor and Bela Zutshi*
}

'Department of Zoology, Bangalore University, Bangalore - 560056, Karnataka, India; bela_zutshi@yahoo.co.in

\begin{abstract}
The present study was aimed to evaluate genotoxicity in peripheral erythrocytes of Labeo rohita reared in two lakes viz., Vengaiah lake - sewage polluted (Lake A) and Yellamallappa Chetty lake - industrially polluted (Lake B) of Bangalore. To assess the micronuclei and nuclear abnormalities in such erythrocytes, blood samples were collected from heart of the freshwater fish, L. rohita anesthetized by MS222. The results were compared with the fish reared in the Hebbal fish farm (Control). The data revealed significantly high frequencies of erythrocytic abnormalities including nuclear as well as cytoplasmic in the fish blood sampled from lake B when compared to those of lake A. Such abnormalities in erythrocytes of fish varied seasonally also with summer exhibiting maximum deformities which can be attributed to the presence of genotoxic pollutants in the selected water bodies. The values were statistically significant at $\mathrm{P}<0.0001$.
\end{abstract}

Keywords: Blood, Erythrocytes, Genotoxicity, Labeo rohita, Pollutants

\section{Introduction}

Surface waters, such as lakes, rivers, and seas contain complex mixtures of pollutants including genotoxic compounds due to the anthropogenic action, which cause adverse effects on public health and aquatic ecosystems ${ }^{26}$. Aquatic environment serves as convenient repositories for man's biological and technological wastes and current awareness of the potential hazards of pollutants in the aquatic environment has stimulated much interest in the use of fish as indicators due to their position in the trophic chain, their sensitivity to low concentrations of genotoxic substances and their ability to metabolize xenobiotics and accumulate pollutants ${ }^{40}$. Hematological study is important in toxicological research because a hematological alteration is a good method for rapid evaluation of the chronic toxicities of a compound. Blood parameters are useful for the measurement of physiological disturbances in stressed fish and thus provide information about the level of damage in the fish ${ }^{28}$. A thin epithelial membrane separates fish blood from the water and any unfavorable change in the water body is reflected in the blood ${ }^{22}$. The study of blood characteristics may corroborate important subsidies of diagnoses and prognoses of morbid conditions in fish populations and therefore, contribute to better comprehending comparative physiology, phylogenetic relations, feeding conditions and other ecological parameters $\frac{28}{}$.

Among the currently available procedures, micronuclei and nuclear abnormalities assays are the most widely applied methods due to its proven suitability for fish species ${ }^{7,21}$. Nuclear abnormalities, such as micronuclei and other nuclear malformations are considered good indicators of cytotoxicity and genotoxicity, respectively ${ }^{21}$. For the determination of genotoxic effect in fish, the micronucleus test as well as the study of the abnormal shape of nuclei is a suitable measure with which the

*Author for correspondence 
presence or absence of genotoxins can be detected in water. The detection of MN and NAs in fish helps us to assess the status of water quality as well as the health of a particular species and any potential risk it might have after consumption ${ }^{37}$.

Schroder (1966) studied the formation of micronuclei in mammalian bone marrow cells for the first time subsequently this assay was developed by Schmid (1975) in mammalian systems. The MN are also known as Howell-jolly bodies in mammals. Like mammalian species, MNT has also been adopted to study genotoxicity in fishes. The formation of morphological nuclear alterations (NAs), was first described in fish erythrocytes by Carrasco et al. (1990). The unique information offered by MNT as a bioindicator for chromosomal aberrations is not available from other methods such as the integrated effect of a variety of environmental stresses on the health of an organism and the population, community, and ecosystem; and the effectiveness of remediation efforts in decontaminating waterways ${ }^{42}$. NAs including blebbed, lobed and notched nuclei and binucleated cells, have been used by several authors as possible indicators of genotoxicity ${ }^{9}$.

The present investigation was conducted to analyse the blood samples for erythrocytic abnormalities in edible fish Labeo rohita reared in fresh water lakes of Bangalore as a consequence of variation in physico chemical parameters of water including detected trace metals.

\section{Materials and Methods}

\subsection{Study Area}

Bangalore also called as Bengaluru is the capital of Karnataka state in South India (Figure 1). It is located at $12.97^{\circ} \mathrm{N} 77.56^{\circ} \mathrm{E}$ and covers an area of $741 \mathrm{~km}^{2}$. The two lakes, Vengaiah lake (Lake A - Area 65 acres; depth 8-10 feet) and Yellamallappa Chetty lake (Lake B - Area 110 ha; depth 10-12 feet) situated near Krishnarajpuram - Hoskote taluk, Bangalore District, Karnataka were selected for the study (Figure 2). Lake A received domestic sewage from an adjacent storm-water drain and lake B those of effluents from pharma-industry and other sources. Hebbal fish farm, which is maintained by the fisheries department was taken as reference site (Control).

\subsection{Analysis of Water Samples}

Water along with the test fish were sampled from Control site, Lake A and Lake B during early morning hours (6:30-7:30 a.m.). The physico-chemical parameters like temperature, $\mathrm{pH}$, BOD, COD, DO, TDS, conductivity, acidity, alkalinity, phosphates, sulphates, nitrates and trace metals such as mercury, lead, aluminium, cadmium, etc of the water samples collected from control, lake A and B were determined by following standard methods by APHA et al., 2005 and atomic absorption spectrophotometry (USEPA, 1983). The values obtained were compared with the Bureau of Indian Standards BIS:10500-1991 (Revised 2012) for lakes. Water quality index was calculated by following Brown et al., 1972; Chatterjee and Razi uddin, 2000.

\subsection{Analysis of Fish Blood Samples}

Labeo rohita was selected as animal model for the present study. Blood was drawn out by Cardiac puncture with a heparinized syringe of test fish previously anesthetized in MS222 by stabbing body wall exactly in midline from the posterior margin of opercular cover and directed dorso-caudally at an angle of $45^{0,24}$. A thin blood smear was spread on a clean dry slide $(2 \times 4 \times 1 \mathrm{~mm})$, fixed in methanol and was left to air-dry. It was then stained with Leishman's stain ${ }^{32}$. The sample's smear was inspected using Zeiss Axidskop Plus microscope connected with camera and computer, equipped with image viewing analysis system. 1,000 erythrocytes of blood smear sampled from fish of lake A, lake B and control site were viewed and classified. For the scoring of micronuclei, the criterion was adopted from Fenech et al. (2003). MN if present should have similar staining as the main nucleus. They should be separated from or marginally overlap with main nucleus as long as there is clear identification of the nuclear boundary. Cellular and nuclear anomalies observed were registered and photographed, and their frequency was calculated.

\section{Statistical Analysis}

Statistical analysis was carried by using MS Excel and statistical software - Graphpad prism 6.05 to evaluate the physico chemical parameters with respect to three water bodies and erythrocytes of fish. Mean of the water and frequency of erythrocytic abnormalities [size $(\mathrm{n}=6)$ ] and standard deviation (mean $\pm \mathrm{SD}$ ) were calculated to quantify their variability which was followed by one way ANOVA to compare significant mean differences of the above mentioned groups. This was followed by Tukey's post-hoc test to compare pair of groups mean of water parameter in water and with erythrocytic abnormalities in fish blood of control group, lake A and lake B. p value at a 

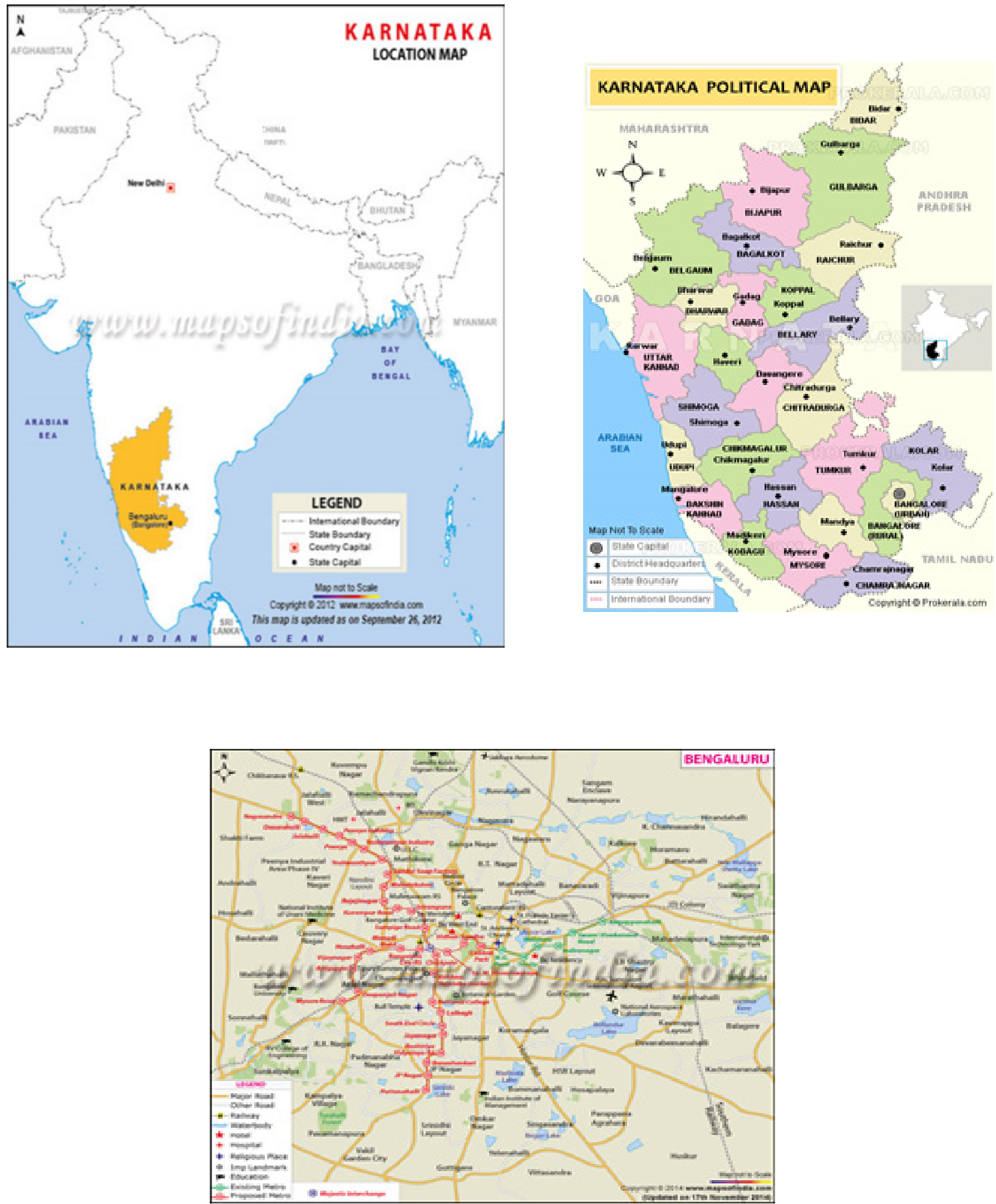

Figure 1. Map of India showing location of Karnataka state and the capital city, Bangalore. 


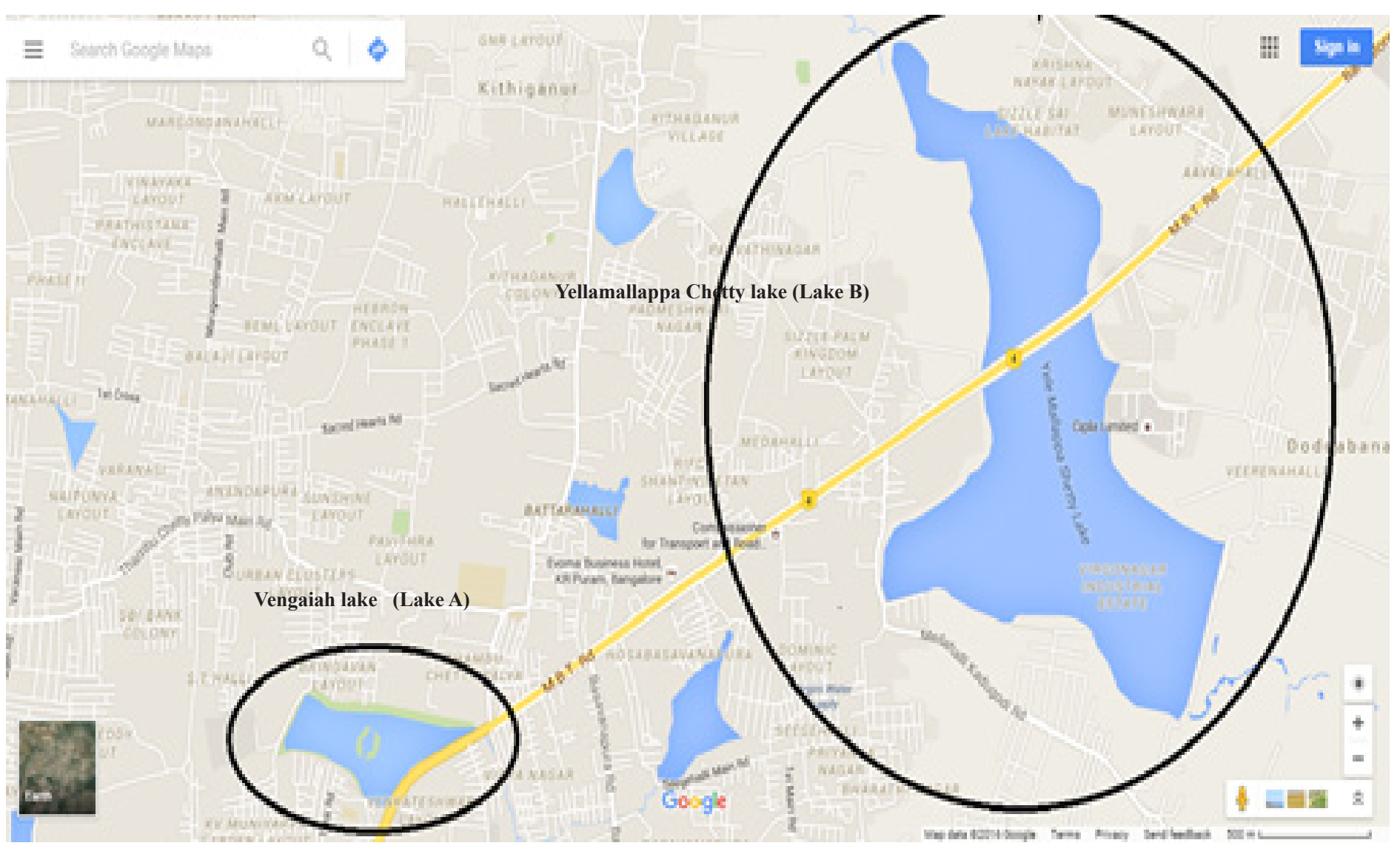

Figure 2. Representation of sampling location: Vengaiah lake (Lake A) and Yellamallappa Chetty lake (Lake B).

significant level of $\mathrm{p}<0.05$ or less indicated significant relationship within variables. Pearson's correlation coefficient between physico chemical parameters of water sampled from control site and lakes (A \& B) and frequency of erythrocytic abnormalities in blood samples of fish collected from these water bodies was also studied.

\section{Results and Discussion}

Physico-chemical parameters are the basic parameters to determine whether a lake is polluted or non polluted. Physicochemical parameters of water sampled from control site were compared with lake A and lake B and inturn with the standard BIS: 10500-1991 (Revised 2012) taking into consideration the three different seasons viz., winter, summer and rainy season. The data was statistically analyzed and is represented in table I \& II showing the significant mean differences at $p<0.001$ and 0.01 . The data revealed high level of pollution in lake B (dur- ing all seasons) when compared to lake A, control site and BIS standard. The high levels of temperature, total suspended solids, chemical oxygen demand, biological oxygen demand, conductivity, turbidity, alkalinity and of trace metal content such as, aluminium, cadmium, copper, iron, lead and mercury was recorded in water samples of lake B. These results might be due to the discharge of industrial effluents from the pharma industry present on the banks of lake B and the agricultural runoff, idol immersion during festival season and discharge of domestic sewage and solid waste through various sources into the water body. The water analysis of lake B indicated significantly high level of trace metals along with other water parameters which were recorded above the BIS limits. This rendered the water quality to be very poor as per water quality index (WQI) (Table III) suggested by Chatterji and Raziuddin (2002) (Table IV) and unsuitable for drinking purpose. Heavy metal contamination may have devastating effects on the ecological balance of the recipient environment and on 


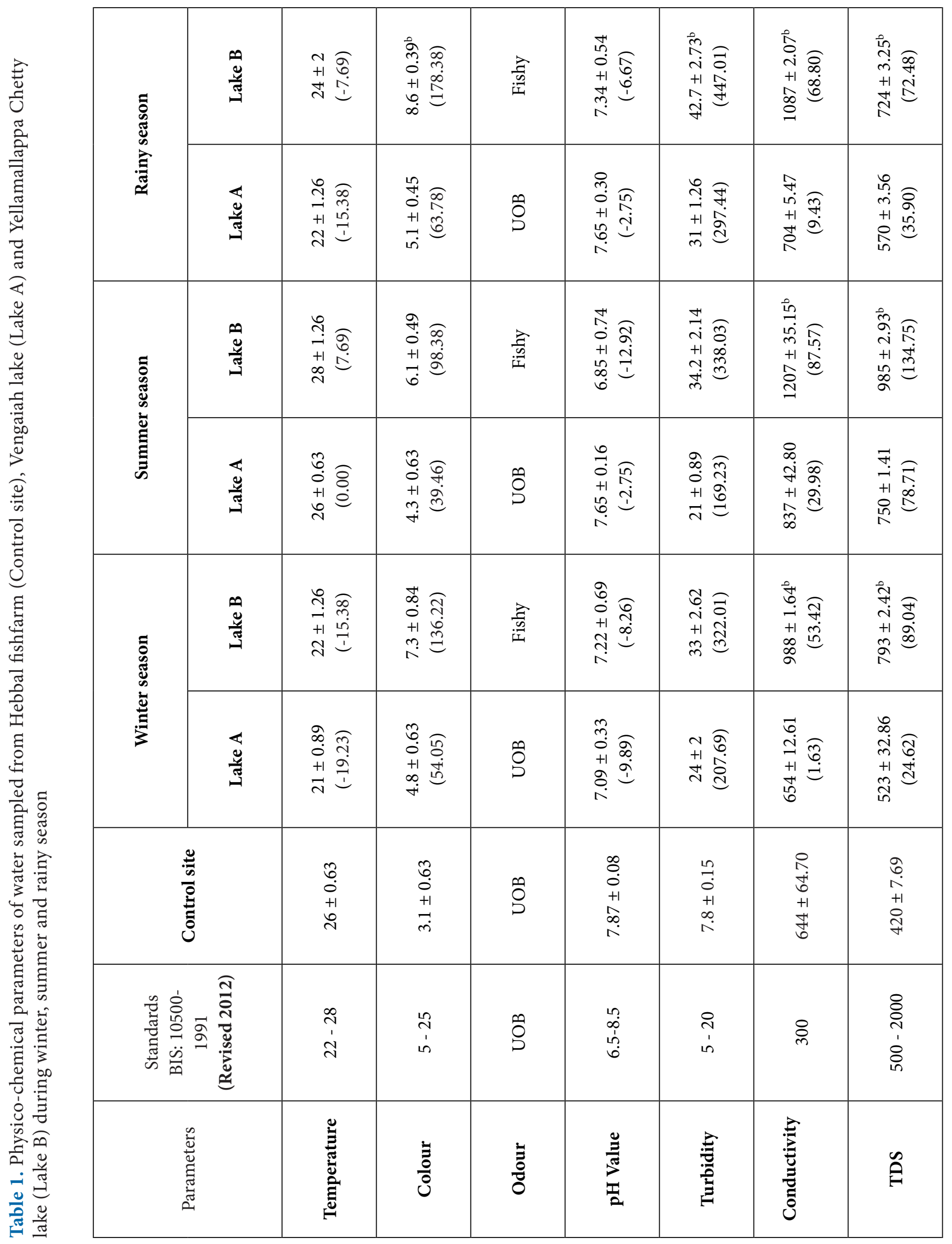




\begin{tabular}{|c|c|c|c|c|c|c|c|c|c|}
\hline $\begin{array}{ll}\infty & \\
\infty & 0 \\
0 & 0 \\
i & 0 \\
+1 & 0 \\
0 & 0 \\
0 & 0 \\
m & \end{array}$ & 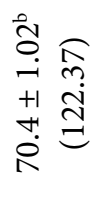 & 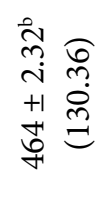 & 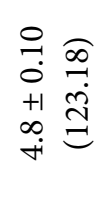 & 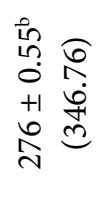 & 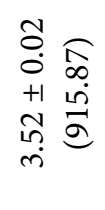 & 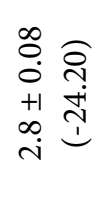 & 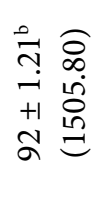 & 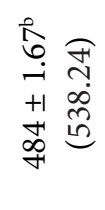 & \multirow{9}{*}{ 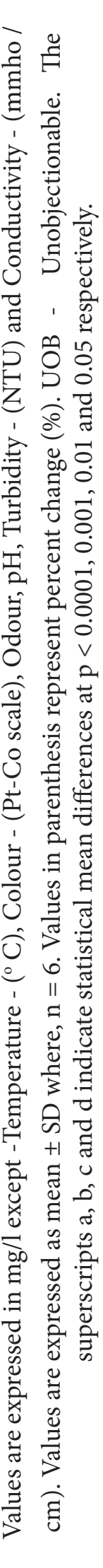 } \\
\hline 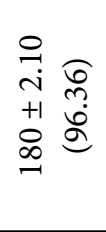 & 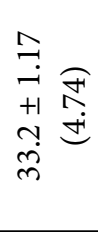 & 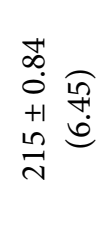 & 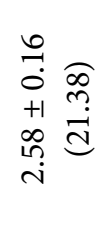 & 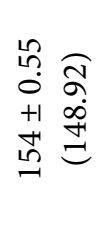 & 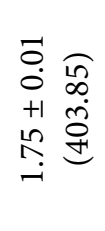 & 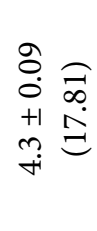 & 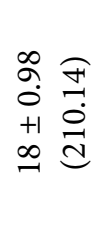 & $\begin{array}{l}0 \\
0 \\
0 \\
0 \\
+1 \\
+ \\
\overrightarrow{0} \\
0\end{array}$ & \\
\hline 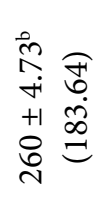 & 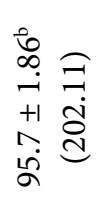 & 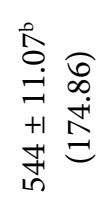 & $\begin{array}{l}\stackrel{0}{0} \\
0 \\
0 \\
+1 \\
\infty \\
\infty \\
\infty \\
\dot{0}\end{array}$ & 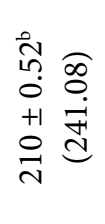 & 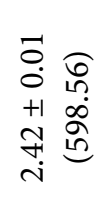 & 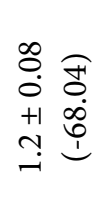 & 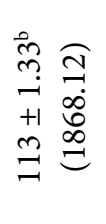 & 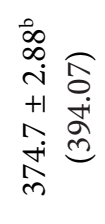 & \\
\hline $\begin{array}{l}0 \\
\infty \\
0 \\
0 \\
+1 \\
0 \\
0 \\
0 \\
0\end{array}$ & 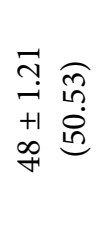 & 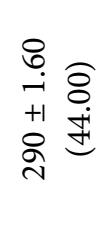 & 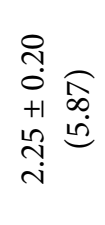 & 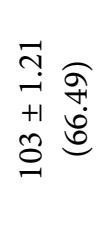 & 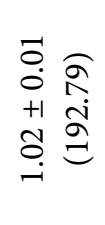 & 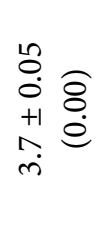 & 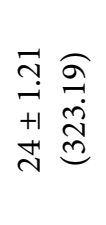 & 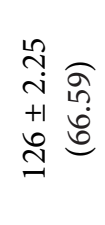 & \\
\hline 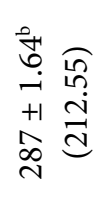 & 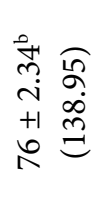 & 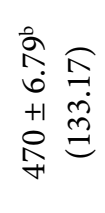 & $\begin{array}{l}0 \\
0 \\
0 \\
+1 \\
+1 \\
i \\
i \\
i n\end{array}$ & 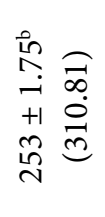 & $\begin{array}{l}\overrightarrow{0} \\
0 \\
0 \\
+1 \\
0 \\
\infty \\
\infty \\
\dot{0} \\
\dot{0}\end{array}$ & 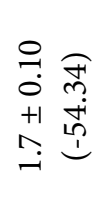 & 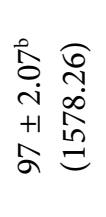 & 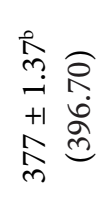 & \\
\hline 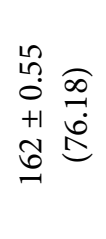 & 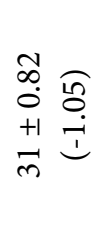 & 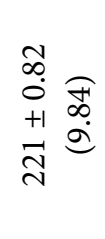 & 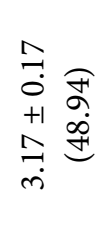 & 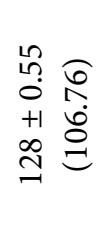 & $\begin{array}{ll} & 0 \\
0 & 0 \\
0 & 0 \\
+1 & 0 \\
o & 0 \\
0 & 0 \\
i\end{array}$ & $\begin{array}{l}\infty \\
0 \\
0 \\
0 \\
+1 \\
\infty \\
\infty \\
\dot{n}\end{array}$ & 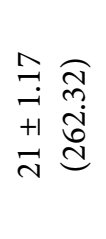 & 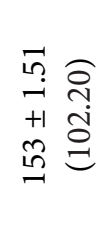 & \\
\hline $\begin{array}{l}\tilde{D} \\
\infty \\
0 \\
+1 \\
\alpha \\
\sigma\end{array}$ & $\begin{array}{l}\tilde{N} \\
\tilde{n} \\
+1 \\
\text { ñ }\end{array}$ & 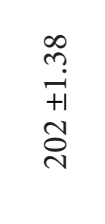 & 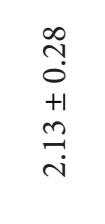 & $\begin{array}{l}\text { ก̃. } \\
0 \\
+1 \\
\text { तु }\end{array}$ & $\begin{array}{l}\overrightarrow{0} \\
0 \\
+1 \\
+1 \\
n \\
0 \\
0\end{array}$ & $\begin{array}{l}\qquad 0 \\
0 \\
0 \\
+1 \\
\stackrel{1}{0} \\
\dot{m}\end{array}$ & $\begin{array}{l}0 \\
\\
0 \\
+1 \\
0\end{array}$ & 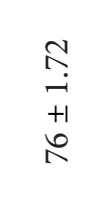 & \\
\hline$\stackrel{-}{\circ}$ & ㄱ & $\begin{array}{l}8 \\
0 \\
1 \\
8 \\
8\end{array}$ & $\begin{array}{l}8 \\
1 \\
\text { f }\end{array}$ & 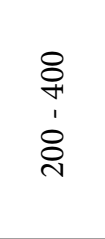 & ' & $\begin{array}{l}0 \\
1 \\
\dot{H}\end{array}$ & $\begin{array}{l}0 \\
1 \\
i\end{array}$ & ષ્స & \\
\hline $\mathscr{H}$ & 吾 & 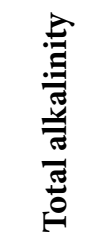 & 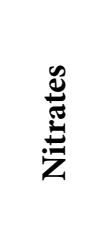 & & 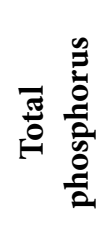 & ○ & )ి & อิ & \\
\hline
\end{tabular}




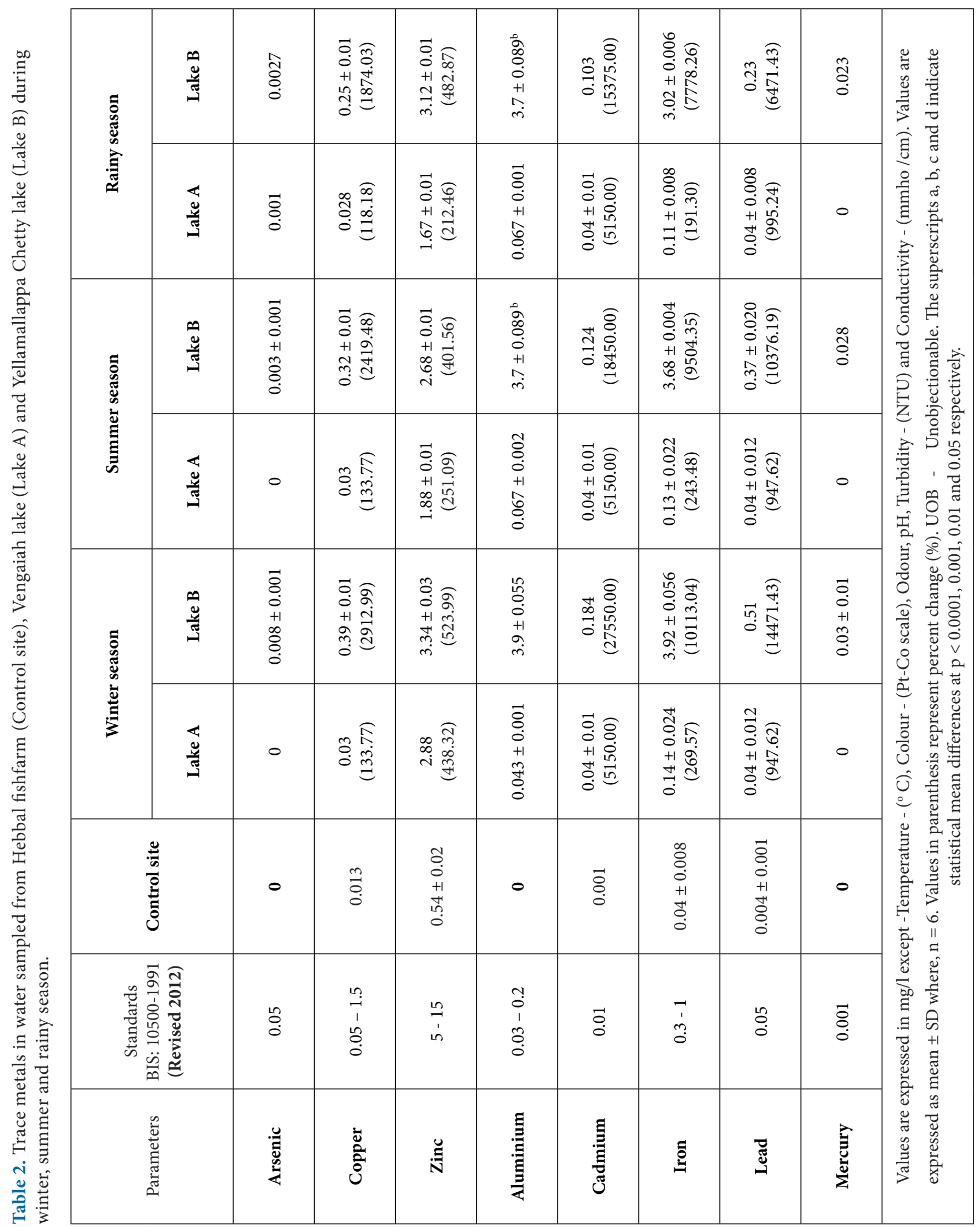


Table 3. Water quality index (WQI) of control site, lake A and lake B during three seasons

\begin{tabular}{|c|c|c|c|}
\hline \multirow{2}{*}{ Water body } & \multicolumn{3}{|c|}{ Seasons } \\
\cline { 2 - 4 } & Winter & Summer & Rainy \\
\hline Control & 36.45 & 1.07 & 36.53 \\
\hline Lake A & 2802.19 & 36.52 & 2110.99 \\
\hline Lake B & & 2570.12 & \\
\hline
\end{tabular}

Table 4. Water Quality Index (WQI) and status of water quality (Chatterji and Raziuddin 2002)

\begin{tabular}{|c|c|}
\hline Water Quality Index level & Water quality status \\
\hline $0-25$ & Excellent water quality \\
\hline $26-50$ & Good water quality \\
\hline $51-75$ & Poor water quality \\
\hline $76-100$ & Very poor water quality \\
\hline$>100$ & Unsuitable for drinking \\
\hline
\end{tabular}

the diversity of aquatic organism $s^{11}$ and are detrimental to the aquatic inhabitants, including fishes ${ }^{27}$.

Micro nuclei test is recommended to be conducted as part of the monitoring protocols in aquatic toxicological assessment programs $\frac{26,39}{3}$. The in vivo micronuclei frequency assay has been widely used as a technique for genotoxicity monitoring of polluted aquatic media and in the screening for the presence of toxic compounds suspected to be genotoxic ${ }^{29,45}$. Morphological alterations in the nuclear envelope in erythrocytes of fish as described by Carrasco et al. (1990) are considered indicators of genotoxic damage and constitutes a complementary analysis to the scoring of micronuclei.

Change in the general structure of erythrocytes such as deformation and swelling along with few nuclear abnormalities was observed in the blood samples of fish from lake A (Figure $1 \mathrm{a}-1 \mathrm{~b}$ ). Large number of nuclear abnormalities which can be classified as blebbed, notched, lobed ${ }^{6}$, eight shaped ${ }^{14}$ and pear shaped nucleus along with ruptured nuclear membrane and oozed out nuclear mass (Figure 1a - 1c) were noted from fish of lake B and are in similar lines with Moharram et al. (2011). They recorded the high percentage of deformed erythrocytes, pear and tear shaped erythrocytes, swelling erythrocytes with fading cytoplasm and indicated a decrease in haemoglobin content of Siganus rivulatus due to polluted water from Egyptian Eastern Mediterranean coast. Cytoplasmic abnormalities were also observed and classified into granulated, ruptured and vacuolated cytoplasm and irregularities in cell membrane of erythrocytes during the present piece of work. Deformed 

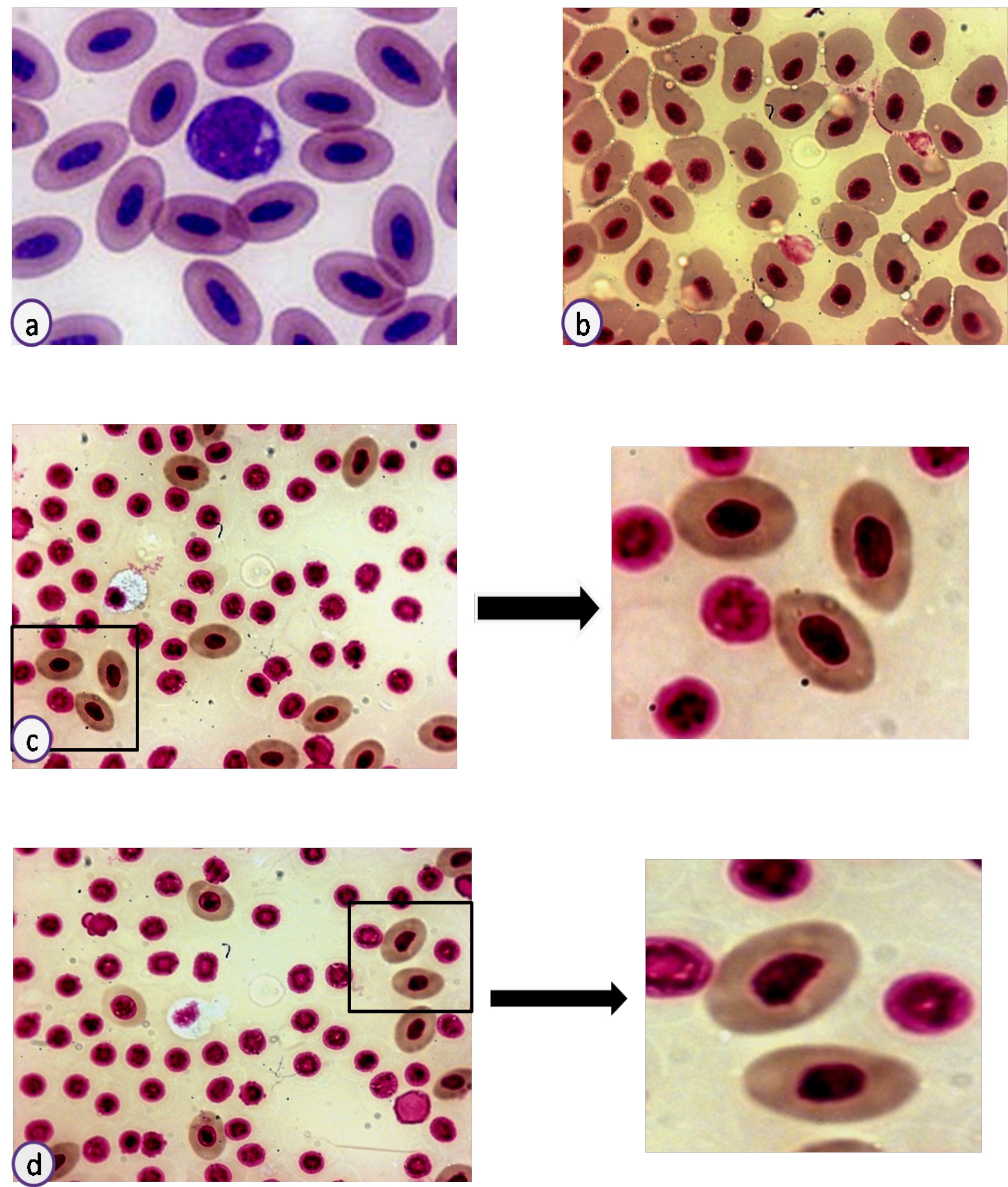

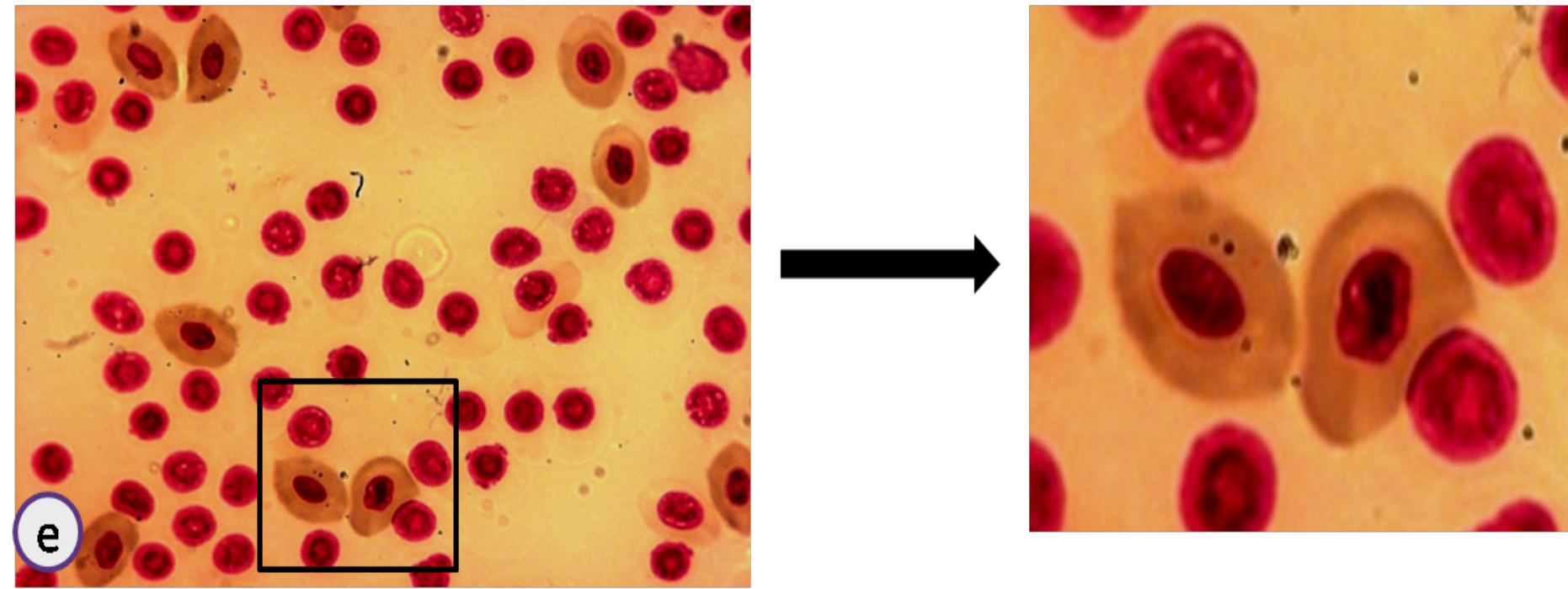

Figure 3a. Erythrocytic abnormalities : a- Normal RBC, b- Deformed RBC, c- blebbed nucleus, d- Notched nucleus and e- Lobed nucleus of Labeo rohita sampled from Hebbal fishfarm (control site), Vengaiah lake (lake A) and Yellamallappa Chetty lake (lake B).
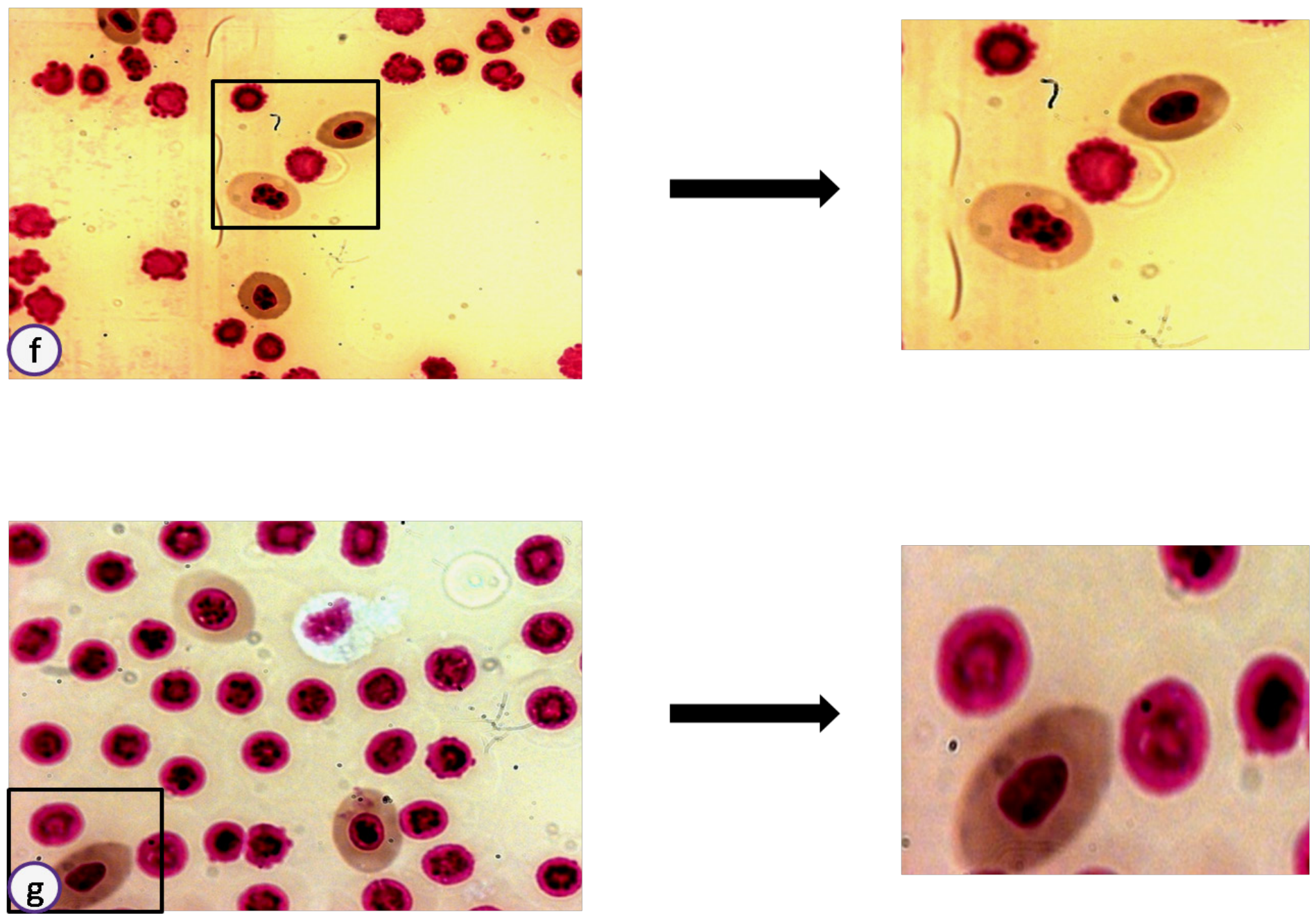

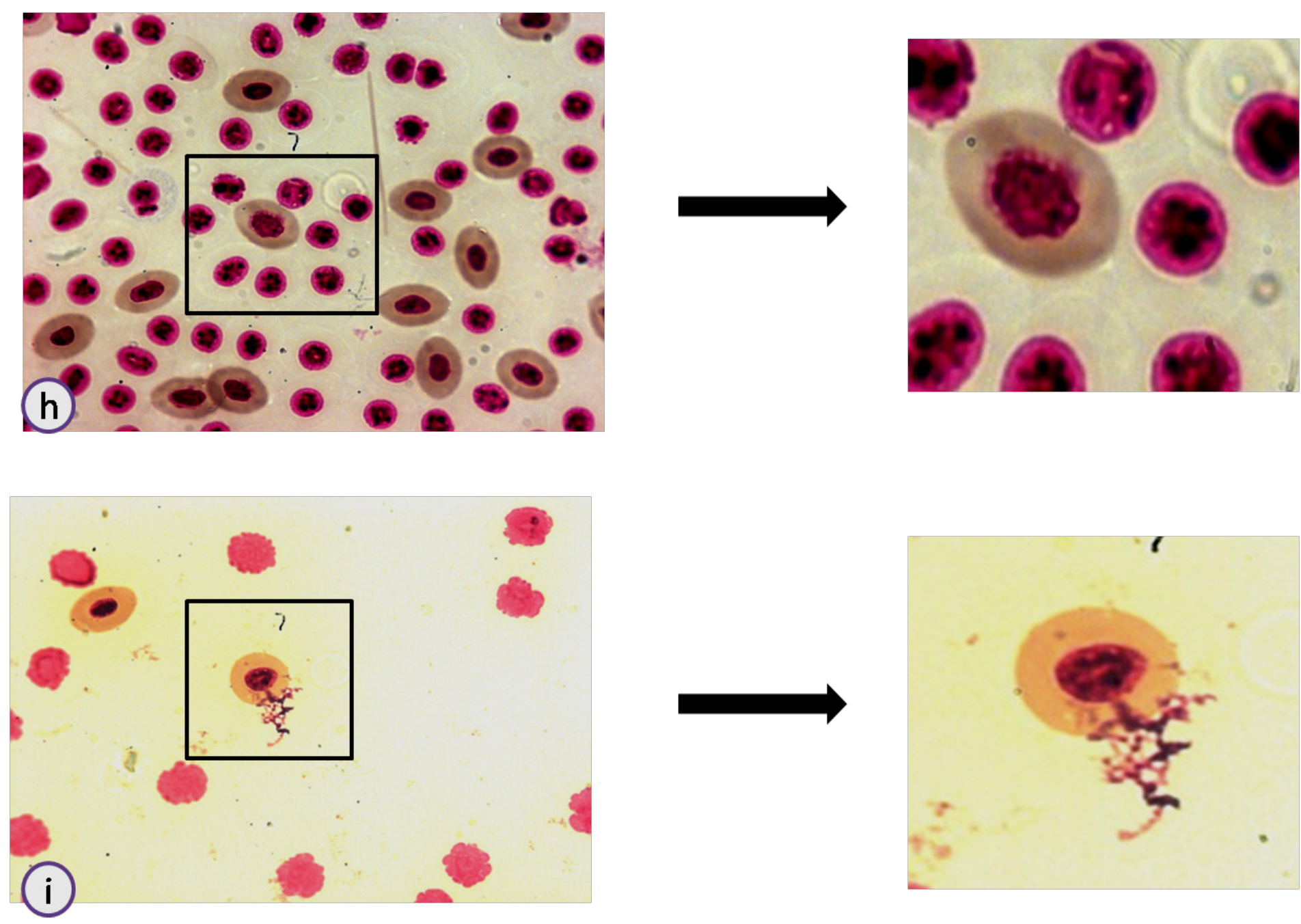

Figure 3b. b. Erythrocytic abnormalities : f- Eight shaped nucleus, g- Pear shaped nucleus, h- Ruptured nuclear membrane and i-oozing of nuclear mass of Labeo rohita sampled from Hebbal fishfarm (control site), Vengaiah lake (lakeA) and Yellamallappa Chetty lake (lake B).
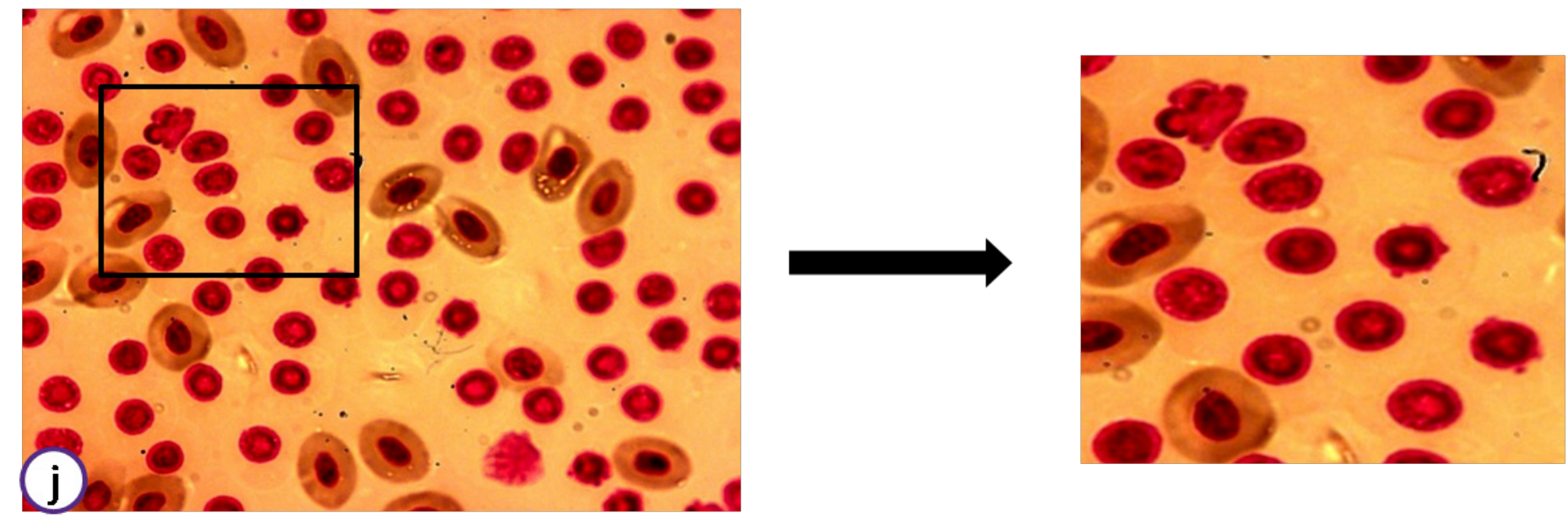

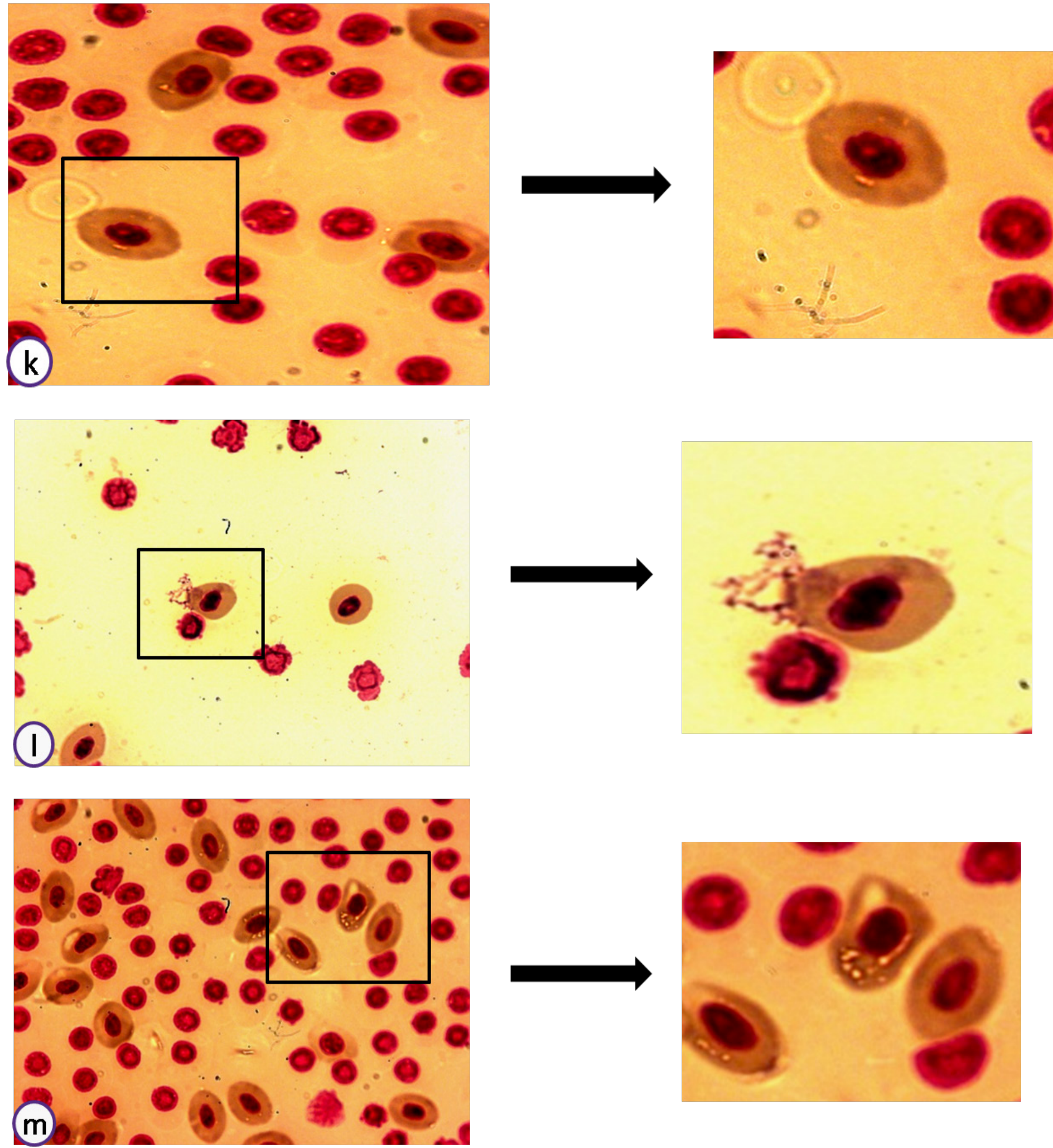

Figure 3c. Erythrocytic abnormalities : j- Disintegrated nucleus and nuclear material, k- Granulated cytoplasm, 1- Ruptured cytoplasm and m-Vacuolated cytoplasm of Labeo rohita sampled from Hebbal fishfarm (control site), Vengaiah lake (lake A)and Yellamallappa Chetty lake (lake B). 
RBCs were also detected in tench on short term exposure to cadmium by Witeska et al. (2006) and due to environmental pollution by Pacheco and Santos (2002). NAs recorded in the present investigation were in conformity with the reports by Furnus et al. (2014) on native fish from Parana river, Argentina. Juliana de Souza et al. (2012) observed two other NA in catfish Cathorops spixii (Ariidae) sampled from different sites on the south-eastern Brazilian coast. They named these NAs as "others" (OT); "heart" or "clover-leaf" shaped which were not classified by Carrasco et al. (1990). Such Nuclear abnormalities (NAs) are a consequence of exposure to environmental and chemical contaminants of genotoxic action ${ }^{?}$.

In the present investigation, erythrocytes of fish sampled from control site were in good condition as the water parameters were within BIS limits. Erythrocytic abnormalities were frequent in samples from lake B (winter $-51.87 \pm 1.9$, summer - $58.34 \pm 2.3$ and rainy $43.08 \pm 2.2)$ when compared to control site $(0.495 \pm 0.11)$ and lake A (winter - $11.61 \pm 1.65$, summer $-8.62 \pm 1.24$ and rainy $6.19 \pm 0.80$ ) (Table V). Maximum abnormalities were observed in blood of fish during summer season in lake B where as such abnormalities were observed during winter followed by summer and rainy season in lake A. Such variations in frequency of erythrocytic abnormalities within the three water bodies are clearly attributed to the type and level of pollution during all the seasons throughout the year.

Heavy metals induced such changes in fishes which are not reversed and caused cytotoxic damage resulting in death of fishes ${ }^{44}$. Erythrocyte swelling, poikilocytosis, vacuolation, amitosis, deformation, and deterioration of cell membranes in Barbus conchonius exposed to chromium were reported by Gill and Pant (1985). Nuclear aberrations such as chromatin condensation, nuclear puffs, and chromatin leakage in the same fish species subjected to cadmium intoxication was again reported by Gill and Pant (1987). Karuppasamy et al. (2005) also reported similar observations as increased fragility, rupture of erythrocyte membrane, and hemolysis and increase in the frequency of nuclear and cytoplasmic abnormalities in Channa punctatus when exposed to sublethal concentration of cadmium. Nuclear abnormalities (NA) in erythrocytes are considered a useful parameter for assessing the genotoxic effects of environmental pollutants in fish, and have been applied successfully in various species such as Anguilla Anguilla, Dicentrarchus labrax, Oncorhynchus mykiss and Centropomus parellelus when exposed to polycyclic aromatic hydrocarbons and resin acids $s^{\underline{30}}, \beta$-naphthoflavone $\mathrm{e}^{\frac{17}{7}}$, metals ${ }^{\underline{3}}$ and from aquatic polluted environment $\underline{21}$ respectively.

In fish, both micronuclei and erythrocytic nuclear abnormalities appear spontaneously and their frequency may be seasonally dependent ${ }^{36}$. The present study also showed similar results. Variation was observed in the frequency of nuclear abnormalities from summer to winter and rainy since, excess evaporation during summer might cause the pollutants to concentrate in water followed by winter which had a post rain effect (Figure 1a - 1c and Table V). During rainy season influx of rain water and outpouring of lakes resulted in lowering of concentration of pollutants. These results were in agreement with Ergene et al. (2007) who reported increase in frequencies of nuclear anomalies such as irregular nucleus shape, vacuolation, binuclei and micronuclei indicating increase in genotoxic effects in fish exposed to water pollution; fluctuation of such abnormalities was reported by Strunjak-Perovic et al. (2009).

Nuclear abnormalities to be considered as precursors of micronuclei was suggested by Walia et al. (2013). Guner and Muranh (2011) reported differences in the erythrocyte micronucleus frequencies to be related to cell kinetics and replacement. They explained that individual and combination exposure of fishes to heavy metals led to an accumulation in the body but this accumulation did not assure an increase in $\mathrm{MN}$ frequency in peripheral blood erythrocytes. Since $\mathrm{Cu}$ and Cd induced only NAs when used alone and in combination but did not induce MN in Gambusia affinis. Similar results were observed in the present study in peripheral blood erythrocytes of rohu fish with a high frequency of nuclear and cytoplasmic abnormalities but absence of micronuclei in lake B which was polluted due to the presence of metals like aluminium, cadmium, copper, iron, lead and mercury.

Further, Von Sonntag (1987) and Steenken (1989) hypothesized that these abnormalities arise due to damage caused to the genetic material by free radical produced under oxidative stress due to the toxicants. Ventura et al. (2008) and Fernandes et al. (2007) reported aneuploidy, an abnormality caused by aneugenic actions of toxicants resulting in formation of binucleated cells and notched nuclei due to tubulin failure and mitotic fuses as was also seen frequent in the rohu fish in the present work. Elaborate sequence of cellular degradation under the impact of toxicants caused hypoxic conditions which resulted in depression of ATP may lead to abnormal shape of erythrocytes was reported by Ateeq et al. (2002). Various erythrocytic abnormalities, Heinz bodies, poikilocytosis, clumped 


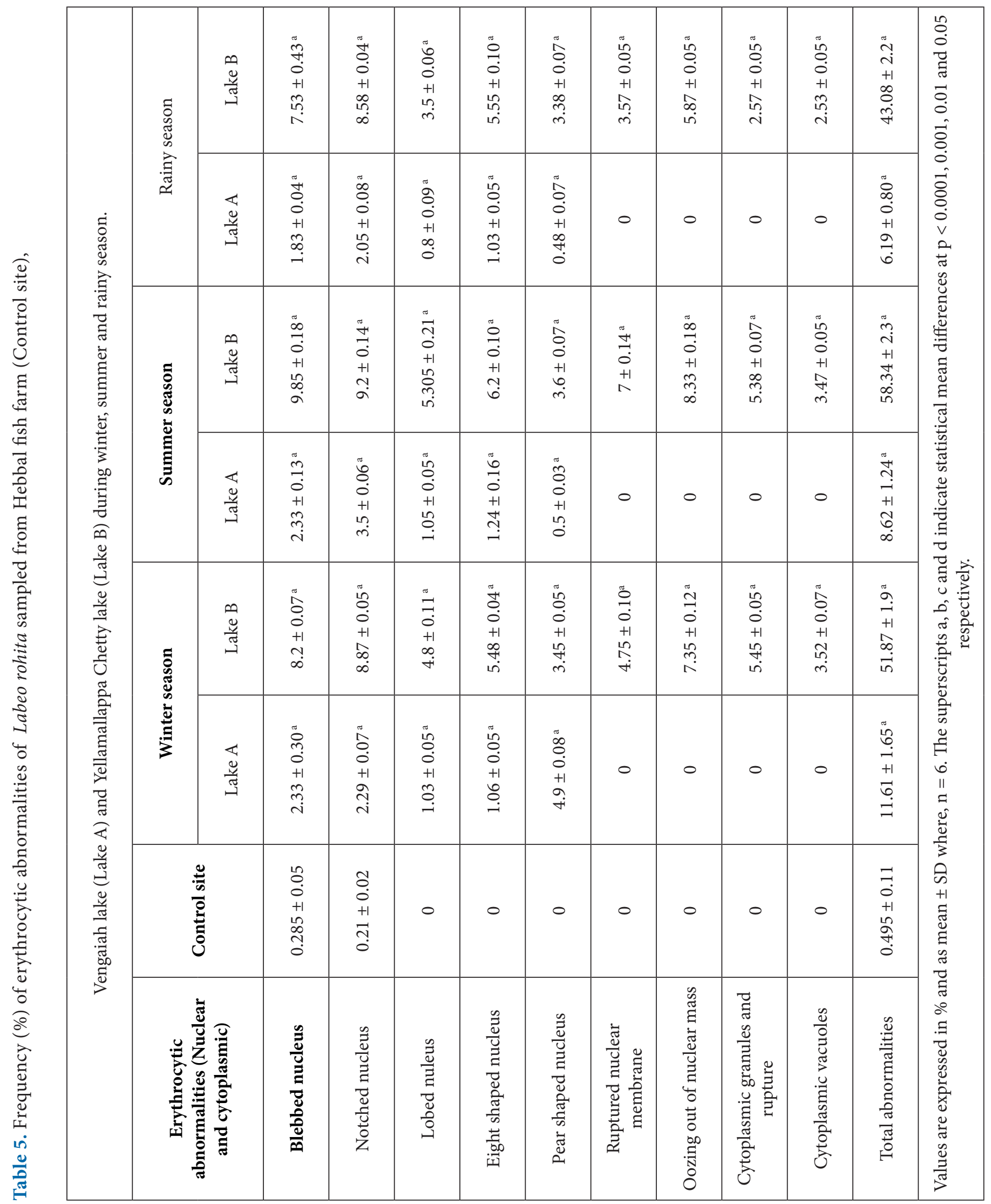


chromatin, ragged cell membranes, altered staining properties, and hemolysis in erythrocytes of Oncorhynchus kisutch from water contaminated with chlorinated sewage was reported by Buckley (1976). Zeni et al. (2002) reported erythrocyte echinocytosis in Ictalurus melas sub-lethally exposed to anionic detergent. It is well known that blood sampling, laboratory techniques, seasonal variations, size, genetic properties, sex, population density, lack of food supply, environmental stress and transportation could affect hematological data 22 .

\section{Conclusion}

To conclude our study on water parameters and Micronuclei test in fish sampled from lake A, lake B and control site during winter, summer and rainy season, it can be stated that variation in levels of physico-chemical parameters due to environmental contaminants including trace metals interfered with fish physiology, disrupted normal processes, induced stress, toxic effects which inturn caused cyto- and geno-toxicity. Thus keeping in view health of these water bodies remedial measures should be undertaken to combat water contamination and its management.

\section{References}

1. APHA, AWWA, and WPCF. Standard methods for examination of water and wastewater (21st Eds: Andrew D Eaton, Clesceri LS, Rice EW, Greenberg AE). The Edition American Public Health Association, Washington, D.C. 2005.

2. Ateeq B, Farah MA, Ali MN and Ahmed W. Induction of micronuclei and erythrocyte alterations in the catfish, Clarias batrachus by 2,4-dichlorophenoxyacetic acid and butachlor. Mutation Research. 2002; 518:135-44. https://doi.org/10.1016/ S1383-5718(02)00075-X

3. Ayllon F and Garcia-Vazquez E. Micronuclei and other nuclear lesions as genotoxicity indicators in rainbow trout Oncorhynchus mykiss. Ecotoxicology and Environmental Safety. 2001; 49:221-5. https://doi.org/10.1006/eesa.2001.2065. PMid:11440474

4. Brown RM, Mc cleiland NJ, Deiniger RA and O' Connor MF. A water quality index - crossing the physical barrier (Jenkis SH ed). Proceedings of International Conference on Water Pollution Research. 1972; 6:787-97.

5. Buckley JA. Heinz body hemolytic anemia in Coho salmon (Oncorhynchus kisutch) exposed to chlorinated wastewater. Journal of the Fisheries Research Board of Canada. 1976; 34:224.

6. Carrasco KR, Tilbury KL and Myers MS. Assessment of the Piscine Micronucleus Test as an in situ biological indicator of chemical contaminant effects. Canadian Journal of Fisheries and Aquatic Sciences. 1990; 47:2123-36. https://doi.org/10.1139/f90237
7. Cavas T and Ergene-Gozukara S. Evaluation of the genotoxic potential of lambda-cyhalothrin using nuclear and nucleolar biomarkers on fish cells. Mutation Research. 2003; 534(1-2):939. https://doi.org/10.1016/S1383-5718(02)00246-2

8. Chatterjee $\mathrm{C}$ and Raziuddin M. Determination of water quality index (WQI) of a degraded river in Asansol Industrial area, Raniganj, Burdwan, West Bengal. Nature, Environment and Pollution Technology. 2002; 1(2):49-59 and 181-9.

9. Da Silva Souza T and Fontanetti CS. Micronucleus test and observation of nuclear alterations in erythrocytes of Nile tilapia exposed to waters affected by refinery effluent. Mutation Research. 2006; 605(1-2):87-93. https://doi.org/10.1016/j. mrgentox.2006.02.010. PMid:16678473

10. Ergene S, Cavas T, Celik A, Koleli N, Kaya F and Karahan A. Monitoring of nuclear abnormalities in peripheral erythrocytes of three fish species from the Goksu Delta (Turkey): Genotoxic damage in relation to water pollution. Ecotoxicology. 2007; 16:385. https://doi.org/10.1007/s10646-007-0142-4. PMid:17380383

11. Farombi EO, Adelowo OA and Ajimoko YR. Biomarkers of oxidative stress and heavy metal levels as indicators of environmental pollution in African cat fish (Clarias gariepinus) from Nigeria Ogun River. International Journal of Environmental Research and Public Health. 2007; 4(2):158-65. https://doi.org/10.3390/ ijerph2007040011

12. Fenech M, Chang WP, Kirsch-Volders M, Holland N, Bonassi $S$ and Zeiger E. Human Micronnucleus Project, HUMN Project: Detailed description of the scoring criteria for the cytokinesis-block micronucleus assay using Isolated human lymphocyte cultures. Mutation Research. 2003; 534:65-75. https:// doi.org/10.1016/S1383-5718(02)00249-8

13. Fernandes TCC, Mazzeo DEC and Marin-Molares MA. Mechanism of micronuclei formation in polyploidizated cells of Allium cepa exposed to trifluralin herbicide. Pesticide Biochemistry and Physiology. 2007; 88:252-9. https://doi. org/10.1016/j.pestbp.2006.12.003

14. Furnus GNA, Caffetti JD, Garcia EM, Benitez MF, Pastori MC and Fenocchio AS. Baseline micronuclei and nuclear abnormalities frequencies in native fishes from the Parana river (Argentina). Brazilian Journal of Biology. 2014; 74(1):217-21. https://doi. org/10.1590/1519-6984.13712

15. Gill TS and Pant JC. Erythrocytic and leukocytic responses to cadmium poisoning in a freshwater fish, Puntius conchonius Ham. Environmental Research. 1985; 36:327. https://doi. org/10.1016/0013-9351(85)90028-3

16. Gill TS and Pant JC. Hematological and pathological effects of chromium toxicosis in the freshwater fish, Barbus conchonius Ham. Water, Air, \& Soil Pollution. 1987; 35:241. https://doi. org/10.1007/BF00290933

17. Gravato $\mathrm{C}$ and Santos MA. $\beta$-naphthoflavone liver EROD and erythrocytic nuclear abnormality induction in juvenile Dicentrarchus labrax L. Ecotoxicology and Environmental Safety. 2002; 52:69-74. https://doi.org/10.1006/eesa.2002.2151. PMid:12051810 
18. Guner U and Muranh FDG. Micronucleus Test, Nuclear Abnormalities and Accumulation of $\mathrm{Cu}$ and $\mathrm{Cd}$ on Gambusia affinis (Baird \& Girard, 1853). Turkish Journal of Fisheries and Aquatic Sciences. 2011; 11:615-22. https://doi.org/10.4194/13032712-v11_4_16

19. Juliana de Souza A, Elisabete de Santis B and Ciro Alberto OR. Nuclear abnormalities in erythrocytes and morphometric indexes in the catfish Cathorops spixii (Ariidae) from different sites on the southeastern Brazilian coast. Brazilian Journal of Oceanography. 2012; 60(3).

20. Karuppasamy R, Subathra S and Puvaneswari S. Hematological responses to exposure to sublethal concentration of cadmium in air breathing fish, Channa punctatus. Journal of Environmental Biology. 2005; 26:123. PMid:16114472

21. Kirschbaum AA, Seriani R, Ranzani-Paiva MJT, Abessa DMS and Pereira CDS. Cytogenotoxicity biomarkers in fat snook Centropomus parallelus from Cananeia and Sao Vicente estuaries, SP, Brazil. Genetics and Molecular Biology. 2009; 32:151-4. https://doi.org/10.1590/S1415-47572009005000007. PMid:21637661 PMCid:PMC3032964

22. Kori-Siakpere O and Ubogu Ewoma O. Sublethal hematological effects of zinc on the freshwater fish, Heteroclarias sp. (Osteichthyes: Clariidae). African Journal of Biotechnology. 2008; 7(12):2068-73. https://doi.org/10.5897/AJB07.706

23. Kori-Siakpere O, Ake JEG and Idoge E. Haematological characteristics of the African snakehead, Parachacnna obscura. African Journal of Biotechnology. 2005; 4(6):527-30.

24. Lucky Z. Hematological investigation of fish. In "methods for the diagnosis of fish diseases" Ed. Hoffman GL, Amerind publishing Co Pvt. Ltd. 1977.

25. Moharram SG, Wahbi OM and El-Greisy ZA. Effect of polluted water from the Egyptian Eastern Mediterranean Coast on reproductive, toxicological and hematological characteristics of Siganus rivulatus. Pakistan Journal of Biological Sciences. 2011; 14:668-81. https://doi.org/10.3923/pjbs.2011.668.681. PMid:22303640

26. Ohe T, Watanabe $\mathrm{T}$ and Wakabasyashi K. Mutagens in surface waters: a review. Mutation Research. 2004; 567:109-49. https:// doi.org/10.1016/j.mrrev.2004.08.003. PMid:15572284

27. Olaifa FG, Olaifa AK and Onwude TE. Lethal and sublethal effects of copper to the African cat fish (Clarias gariepnus). African Journal of Biomedical Research. 2004; 27:9-15.

28. Osman A, Ali E, Hashem M, Mostafa M and Mekkawy I. Genotoxicity of two pathogenic strains of zoosporic fungi (Achlya klebsiana and Aphanomyces laevis) on erythrocytes of Nile tilapia Oreochromis niloticus niloticus. Ecotoxicology and Environmental Safety. 2010; 73:24-31. https://doi.org/10.1016/j. ecoenv.2009.08.021. PMid:19811832

29. Ossana NA, Casta-e PM, Poletta GL, Mudry MD and Salibian A. Toxicity of waterborne copper in premetamorphic tadpoles of Lithobates catesbeianus (Shaw, 1802). Bulletin of Environmental Contamination and Toxicology. 2010; 84:712-5. https://doi. org/10.1007/s00128-010-0014-0. PMid:20440472
30. Pacheco M and Santos MA. Induction of EROD activity and genotoxic effects by polycyclic aromatic hydrocarbons and resin acids on the juvenile eel (Anguilla anguilla L). Ecotoxicology and Environmental Safety. 1997; 38:252-9. https://doi.org/10.1006/ eesa.1997.1585. PMid:9469877

31. Pacheco M and Santos MA. Biotransformation, genotoxic and histopathological effects of environmental contaminants in European ell (Anguilla anguilla L.). Ecotoxicology and Environmental Safety. 2002; 53:331-47. https://doi.org/10.1016/ S0147-6513(02)00017-9

32. Pal GK and Pal P. Preparation and examination of blood smears. Text book of practical physiology, 2nd edn. Oriental Blackswan, Chennai. 2006; p. 456.

33. Schmid W. The micronucleus test. Mutation Research. 1975; 31:9-15. https://doi.org/10.1016/0165-1161(75)90058-8

34. Schroder TM. Cytogenetische and cytologische befunde bei enzymopenischen panmyelo pathien and pancytopanien (Familiare panmyelopathien fanconi glutathionreduktasemangel anamie megalobelastare Vitamin B). Humangenzetik. 1966; 2:287-316.

35. Steenken S. Purine basis, nucleosides and nucleotides: aqueous solution redox chemistry and transformation reactions of their radical cations and e- and $\mathrm{OH}$ adducts. Chemical Reviews. 1989; 89:503-20. https://doi.org/10.1021/cr00093a003

36. Strunjak-Perovic I, Coz-Rakovac R, Topic Popovic N and Jadan M. Seasonality of nuclear abnormalities in gilthead sea bream Sparus aurata (L.) erythrocytes. Fish Physiology and Biochemistry. 2009; 35:287-91. https://doi.org/10.1007/s10695008-9208-3. PMid:19343523

37. Talapatra SN and Banerjee SK. Detection of micronucleus and abnormal nucleus in erythrocytes from the gill and kidney of Labeo bata cultivated in sewage-fed fish farms. Food and Chemical Toxicology. 2007; 45:210-15. https://doi.org/10.1016/j. fct.2006.07.022. PMid:17034922

38. U. S. Environmental Protection Agency (USEPA). Metals (Atomic absorption methods)-General Procedure for Analysis by Atomic absorption. Methods for the Chemical Analysis of Water and Wastes. EPA-Methods - 600/4-79-020, Cincinnati, Ohio, USA. 1983.

39. Udroiu I. The micronucleus test in piscine erythrocytes. Aquatic Toxicology. 2006; 79:201-4. https://doi.org/10.1016/j.aquatox.2006.06.013. PMid:16846653

40. Van der oost R, Beyer J and Vermeulen NPE. Fish bioacumulation and biomarkers in enviromental risk assessment: a review. Environmental Toxicology and Pharmacology. 2003; 13:57-149. https://doi.org/10.1016/S1382-6689(02)00126-6

41. Ventura BC, Angelis DF and Marin-Molares MA. Mutagenic and genotoxic effects of the atrazine herbicide in Oreochromis nilotics (Perciformes, Cichlidae) detected by the micronuclei test and the comet assay. Pesticide Biochemistry and Physiology. 2008; 90:42-51. https://doi.org/10.1016/j.pestbp.2007.07.009

42. Villela IV, De Oliveira IM, Da Silva J and Henriques JA. DNA Damage and Repair in haemolymph cells of Golden mussel exposed to environmental contaminants. Mutation Research. 2006; 605:78-86. https://doi.org/10.1016/j.mrgentox.2006.02.006. PMid:16697250 
43. Von Sonntag C. The Chemical Basis of Radiation Biology. New York: Taylor and Francis. 1987; p. 516.

44. Walia GK, Handa D, Kaur H and Kalotra R. Erythrocyte abnormalities in a freshwater fish, labeo rohita exposed to tannery industry effluent. IJPBS. 2013; 3(1):287-95.

45. Wirz MVMA, Saldivia PH and Freire-Maia DV. Micronucleus test for monitoring genotoxicity of polluted river water in Rana catesbeiana tadpoles. Bulletin of Environmental Contamination and Toxicology. 2005; 75:1220-7. https://doi.org/10.1007/s00128005-0879-5. PMid:16402315
46. Witeska M, Jezierska B and Wolnicki J. Respiratory and hematological response of tench, Tinca tinca (L.) to a short-term cadmium exposure. Aquaculture International. 2006; 14:141-52. https://doi.org/10.1007/s10499-005-9020-3

47. Zeni C, Bovolenta MR and Stagni A. Occurrence of echinocytosis in circulating RBC of black bullhead, Ictalurus melas (Rafinesque), following exposure to an anionic detergent at sublethal concentrations. Aquatic Toxicology. 2002; 57:217. https:// doi.org/10.1016/S0166-445X(01)00203-X 